\title{
Effects of Organic Materials, Chitosan, Wood Vinegar, and EM Active Solution on Soil Microbial and Growth in Chinese Cabbage
}

\author{
Soon Jae Jeong ${ }^{1}$, Mi Yong Cho', Woon Young Seok', Sang Lok Lee², Hyoung Joo Lee ${ }^{3}$ and \\ Ju Sung $\mathrm{Oh}^{1}$ * \\ ${ }^{1}$ College of Natural Resources and Life Science, Dong-A University, Busan 604714, Korea \\ ${ }^{2}$ College of Engineering, Dong-A University, Busan 604-714, Korea \\ ${ }^{3}$ Monsanto Korea, INC., Seoul 100-710, Korea
}

Received February 14, 2011 /Accepted April 5, 2011

\begin{abstract}
This study was conducted to investigate the effects of organic materials, chitosan, wood vinegar, and EM active solution, on soil microbial and growth in Chinese cabbage. The organic materials were treated with chitosan, wood vinegar, and EM (effective microoganism) active solution, and the treatment concentration was 100 times solution and 1,000 times solution level with foliar application. The results are summarized as follows: Among foliar application of organic materials treatment plot[?], with 1,000 times solution level of chitosan was effective in inhibiting microbial growth in Chinese cabbage compared to other plots and control. The microorganism number in the soil for cultivation of Chinese cabbage increased with organic materials treatment plot as compared with control. Especially, 1,000 times solution level of chitosan showed the most significant effect.
\end{abstract}

Key words : Chitosan, Wood Vinegar, effective microorganism (EM), microorganisms

\section{서 론}

농업에서 그 동안 생산력을 향상시키기 위해 화학비료 및 농약의 무분별한 사용으로 인한 문제점이 부각되기 시작하면 서 농업생산의 안전성, 지속성 및 환경보전을 동시에 추구할 수 있는 지속가능하고, 환경친화적인 유기농업에 대한 중요성 이 부각되고 있으며[21,22], 재배농가도 증가하고 있다. 이와 더불어 최근 국민경제의 상승과 삶의 질적 향상으로 생명, 농 산물에 대한 안전 등이 요구되고 있어 친환경농업인 유기농업 의 중요성이 높아지고 있다. 유기농업은 농약과 화학비료 대 신 각종 유기농자재, 유기질퇴비 등을 사용하여 지력을 증진 시킨 후 천적, 미생물농약, 각종 유기농자재를 사용하여 병해 충을 예방 - 방제하여 안전하고 영양가치가 높은 농산물을 생 산하는 농법을 말한다. 현재 우리나라에서 친환경농산물 생산 을 위해 사용 가능한 자재는 크게 토양개량과 작물생육을 위 하여 사용이 가능한 자재와 병해충관리를 위하여 사용이 가능 한 자재로 나누어 허용하고 있다[17].

본 연구는 친환경농산물 생산을 위하여 사용 가능한 자재 중 친환경인증 재배농가에서 많이 사용하고 있는 키토산, 목 초액 및 EM (effective microoganism) 활성액을 공시재로로 선정하여 시험을 수행하였다. Chitosan은 게나 가재, 새우 껍 데기에 들어 있는 키틴을 탈아세틸화하여 얻어낸 키틴의 유도 체로서 농업분야에서는 토양개량용 및 병해충방제용으로 사

*Corresponding author Tel : +82-51-200-6535, Fax : +82-51-200-6536

E-mail : o-bagsa@hanmail.net
용하고 있는 자재이다. 키토산은 몇가지 식물병원균에 대한 항균활성도 보고되고 있고 $[3,4,5]$, 세포의 활성화에 의한 식물 체의 생장촉진효과가 있어 작물재배뿐만 아니라 항균활성 [10], 항종양 활성[15], 콜레스테롤 저하작용[20] 등 임상실험에 도 많이 이용되고 있다.

목초액은 천연목재를 가열하여 탄화하는 과정에서 기화하 는 가스를 냉각원리에 의해 기체와 액체로 분리하여 추출한 액제이다. 주로 $80 \sim 150^{\circ} \mathrm{C}$ 에서 채취되며, 목초액에 함유된 주 요산으로서는 초산, 프로피온산, 부틸산 등 6종, 알코올류는 메타놀, 아세톤인 등 10종, 페놀류로서는 크레졸, 에틸페놀 등 12 종 및 아세톤이나 에스텔류와 같은 중성물질로 구성되어 있다[2,9].

EM (Effective Microorganisms)은 복합 유용 유기농자재로 서 발효 - 정균 - 합성 그리고 항산화물질을 생성하는 미생물 즉 유산균, 효모균, 방선균, 누룩균 및 광합성세균 등 80 여 종 의 미생물이 포함되어 있는 유기농자재이다. EM은 비옥한 토 양속에서 채취한 미생물을 엄선, 합성배양한 것으로 동정결과 Lactobacillus계가 수종이었으며, YM배지에서 Yeast계로 Candida Versatilis가 조사되었다. 그리고 광합성세균으로 Cyanobacteria등이 확인된 미생물제제이다[6]. EM은 지력증 진, 병충해방제, 축산 환경과 사료 효율개선 및 수질개선에도 효과가 있는 것으로 알려져 있다[17].

따라서 본 연구는 안전한 농산물을 생산하기 위한 기초연구 로서, 공시재료는 현재 친환경 재배농가에서 화학비료와 농약 대신 많이 사용하고 있는 유기농자재 중 키토산, 목초액 및 $\mathrm{EM}$ 활성액 3종류를 선정하여 우리나라 국민들이 많이 이용하 
고 있는 엽채류인 배추를 공시작물로 하여 생육 및 토양 미생 물상에 미치는 영향에 대해 시험하였다.

\section{재료 및 방법}

본 시험은 2009년 8월부터 동년 12 월 10 일까지 경남 김해시 대동면 초정리에 소재한 동아대학교 종합농장의 플라스틱 하 우스 내에서 수행하였다.

\section{시험처리 내용}

공시재료는 현재 친환경농업 인증농가에서 화학비료와 농 약 대용으로 많이 사용하고 있는 유기농자재인 키토산, 목초 액 및 $\mathrm{EM}$ 활성액을 사용하였다.

시험 재배포장은 8 월 23 일에 $10 \mathrm{a}$ 당 퇴비 $1,000 \mathrm{~kg}$ 을 기비처 리하고, 경운한 다음 처리구를 $150 \times 80 \mathrm{~cm}$ 로 이랑을 만든 후 8월 27일에 각 처리구에 유기농자재인 키토산, 목초액 및 $\mathrm{EM}$ 활성액을 공히 100 배핵으로 동일하게 토양 관주 처리하였으 며, 무처리구인 대조구는 농업용수로 토양 관주 처리하였다. 그리고 엽면처리는 키토산, 목초액 $\mathrm{EM}$ 활성액의 엽면살포 농 도를 각각 100 배액 및 1,000 배액으로 하여 배추 정식 후 15 일 간격으로 3회 엽면살포하였다. 정식은 9월 3일에 하였으며, 처리구당 재식본수는 20 주로 하였고, 배추수확은 12 월 3 일에 실시하였다. 공시품종은 동부한농종묘의 “흑장미(Black rose)"를 사용하였다. 시험구배치는 난괴법 3반복으로 하였고, 포장관리는 농촌진흥청 작물별 재배기준에 따랐으며, 시험재 배 기간 중 농약은 사용하지 않았다.

\section{생육특성 조사}

수확 후 생육조사는 처리구당 평균치가 되는 10 주씩을 표본 추출하여 농사시험연구 조사기준에 준하여 실시하였다[12]. 생육조사 항목 중 엽장 및 엽폭은 결구엽 중 가장 길이가 큰 엽을 조사하였다. 그리고 총 엽수, 외엽수(결구를 형성하고 있 지 않은 잎의 수), 내엽수(결구를 형성하여 식용으로 이용할 수 있는 잎의 수), 주중(뿌리를 제외한 포기 전체의 무게), 구중 (결구된 부분의 무게), 구고(결구된 부위의 최대 종경) 및 구폭 (결구된 부위의 최대 횡경) 등을 조사하였다.

\section{토양미생물 분석}

공시작물 재배지 토양의 미생물 조사는 유기농자재인 키토 산, 목초액 및 $\mathrm{EM}$ 활성액을 처리 전 - 후 토양을 각각 토양 표 면으로부터 깊이 $10 \mathrm{~cm}$ 까지의 흚을 채취한 후, 가는 체(20 $\mathrm{mesh}$ 로 쳐서 $0.85 \%(\mathrm{w} / \mathrm{v}) \mathrm{Nacl}$ 멸균수에 현탁시킨 다음 선 택배지를 사용하여 유기농자재의 엽면살포 농도 및 균 종류별 로 희석법과 한천배지 평판 도말법으로 토양내의 미생물의 종류별 계수를 실시하였다[16]. 실험에 사용한 선택배지의 종 류로는 일반 세균을 선별하는 Tryptic Soy Agar (TSA), 방선균
을 선별하는 Actinomycetes Isolation Agar (AIA), 일반 곰팡 이의 선별에 사용하는 Potato Dextrose Agar (PDA)에 $50 \mu \mathrm{g} / 1$ 의 Chloramphenicol을 함께 사용하였으며, 트리코데마를 선 별하는데 사용하는 Malt Extract Agar(MEA)에 항생제로 Chlorotetracyclin을 $20 \mu \mathrm{g} / 1$ 첨가한 배지를 사용하였다. 선별 배지에 도말한 미생물은 $30^{\circ} \mathrm{C}$ 에 6 일간 배양하여 형성된 콜로 니수를 측정하였다. 총균수는 이들 선택배지를 사용하여 계수 된 개별 미생물들의 생균수의 총 합계로 계산하였다.

\section{결 과}

\section{생육특성}

유기농자재인 키토산, 목초액 및 $\mathrm{EM}$ 활성액 처리에 따른 배추의 생육특성인 엽장, 엽폭 및 엽수 등을 조사한 결과를 살펴보면 엽장 및 엽폭은 공히 키토산 1,000 배액 처리구에서 가장 높게 나타났다. 전체 엽수에 있어서 외엽수(결구를 형성 하고 있지 않은 잎의 수)는 목초액 1,000 배액 처리구에서 가장 많았다. 내엽수(결구를 형성하여 식용으로 이용할 수 있는 잎 의 수)는 키토산 1,000 배액 처리구에서 가장 많았는데 결구배 추는 일반적으로 외엽수보다 내엽수가 많은 것이 상품가치가 높다. 내엽수와 외엽수를 합한 총 엽수는 키토산 1,000 배액 처리구에서 가장 많았다. 이러한 결과로 볼 때 유기농자재 처 리농도간에는 100 배액 처리보다 1,000 배액 처리에서 생육이 비교적 양호하게 나타났는 데 이는 엽채류에서 대체적으로 엽 면처리 농도가 500 1,000배액을 사용하고 있는데 본 연구에서 도 이와 유사한 결과를 보였다. 유기농자재간에는 키토산처리 에서, 유기농자재 전 처리구간에는 키토산 1,000 배액 처리구 에서 배추의 엽특성이 양호하게 나타났다.

유기농자재인 키토산, 목초액 및 $\mathrm{EM}$ 활성액 처리에 따른 배추의 생육특성인 주중(株重), 구중(球重), 구고(球高) 및 구 폭(球幅)을 조사한 결과를 살펴보면 뿌리를 제외한 포기 전체 의 무게인 주중(株重)은 키토산 1,000 배액 처리구에서 가장 무 거웠고, 목초액 100 배액 처리구에서는 가장 낮았다. 결구된 부분의 무게인 구중(球重)은 키토산 1,000 배액 처리구에서 높 았고, 결구된 부위의 최대 종경인 구고(球高) 및 결구된 부위의 최대 횡경인 구폭(球幅)은 공히 키토산 1,000 배액 처리구에서 가장 높게 나타났다. 이러한 연구결과로 볼 때 처리간에는 무 처리구인 대조구에 비해 유기농자재를 사용한 처리구에서 대 체적으로 생육이 양호하였으며, 유기농자재간에는 키토산 처 리에서 가장 생육이 좋았고, 그 다음으로 $\mathrm{EM}$ 활성액 처리, 목초액 처리 순으로 나타났다. 그리고 유기농자재 처리농도간 에는 100 배액 처리 보다는 1,000 배액 처리에서 생육이 좋았고, 유기농자재 전 처리구간에는 키토산 1,000 배액 처리구에서 생 육이 양호하였다.

이상의 결과를 종합하면 유기농자재인 키토산, 목초액 및 $\mathrm{EM}$ 활성액을 정식 전 토양관주 처리와 정식 후 15 일 간격으로 
3회 엽면살포하여 배추의 생육특성을 조사한 결과 생육특성 에서는 무처리구인 대조구보다 유기농자재인 키토산, 목초액 및 EM 활성액을 엽면살포한 처리구에서 다소 생육이 양호하 였으며, 유기농자재간에는 키토산이 양호하였고, 전 처리구 간 에는 키토산 1,000 배액 처리구에서 배추의 생육이 양호하였다. Jeong 등[7,8]은 유기농자재인 키토산, 목초액 및 $\mathrm{EM}$ 의 농도를 각각 100 배, 500 배 및 1,000 배액을 토마토에 엽면살포한 결과 키토산 500 배액 처리구에서 초기생육이 양호하였다고 보고하 였고, 가지 및 잎상추에서는 키토산과 목초액의 처리농도를 공히 200배액, 400 배액 및 800 배액으로 처리한 결과 800 배액을 엽면처리했을 때 생육이 양호하였다고 하였다. 이런 결과로 볼 때 작물별이나 토질에 따라 다소 차이는 있으나 대체적으로 100 배액 처리보다는 500 배액 및 1,000 배액 처리에서 생육이 양호한 것으로 나타나 본 연구와 유사한 경향을 보였다.

\section{토양미생물상 분석}

유기농자재인 키토산, 목초액 및 $\mathrm{EM}$ 활성액 처리 전·후 토양을 채취하여 각각의 토양에 존재하는 총 균수와 균종별 미생물수를 조사하여 토양미생물의 구성 및 균들의 수적인 변화를 조사하였는데 본 시험에서는 작물 재배에 가장 중요한 역할을 하는 일반 세균, 곰팡이, 트리코데마 및 방선균의 수를 조사한 결과는 다음과 같다.

유기농자재인 키토산, 목초액 및 $\mathrm{EM}$ 활성액 처리 전·후의 일반 세균수의 변화는 Fig. 1 에서 보는 바와 같다. 유기농자재 처리 전 토양의 세균수는 $55.67 \times 10^{3} \mathrm{CFU} / \mathrm{g}$ 이었으나 토양관주 및 엽면처리를 하고, 배추를 수확한 후의 세균수를 조사한 결 과 대조구를 제외한 전 처리구에서 유기농자재 처리 전에 비 해 다소 증가하였다. 유기농자재 간에는 키토산 100 배액 및 1,000 배액 처리구에서 가장 많았으며, 목초액 100 배액 처리구 에서 $60.33 \times 10^{3} \mathrm{CFU} / \mathrm{g}$ 로 가장 적었다.

유기농자재인 키토산, 목초액 및 $\mathrm{EM}$ 활성액 처리 전·후의 곰팡이수의 변화는 Fig. 2 에서 보는 바와 같다. 처리 전 토양의 곰팡이수는 $15.33 \times 10^{3} \mathrm{CFU} / \mathrm{g}$ 이였으며, 배추를 수확한 후의 곰팡 이 수를 조사한 결과 유기농자재 전 처리구에서 다소 감소한 경 향을 보였고, 대조구에서 $13.67 \times 10^{3} \mathrm{CFU} / \mathrm{g}$ 로 적게 감소하였다.

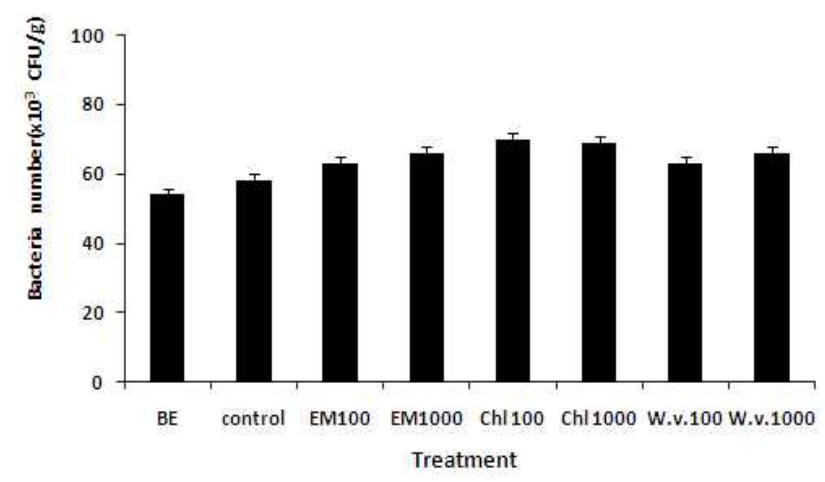

Fig. 1. Changes in the number of bacteria in cultivation soil of Chinese cabbages.
유기농자재인 키토산, 목초액 및 $\mathrm{EM}$ 활성액 처리 전·후의 트리코데마수의 변화는 Fig. 3에서 보는 바와 같다. 처리 전 토양의 트리코데마수는 $20.33 \times 10^{3} \mathrm{CFU} / \mathrm{g}$ 이였으며, 처리후에 는 대조구를 포함한 전 처리구에서 약간 증가하였으나 일정한 경향은 없었다. 시험결과 키토산 1,000 배액 처리구에서 $27.33 \times 10^{3} \mathrm{CFU} / \mathrm{g}$ 로 가장 많이 증가하였다. 트리코데마는 병 원성 곰팡이를 잡아 먹는 천적 곰팡이로서 Rhizoctonia와 같 은 난방제성 토양전염성 병해를 일으키는 병원균을 억제하는 효과가 뛰어나다고 알려져 식물병 방제용으로 널리 사용되고 있는 미생물이다[1].

유기농자재인 키토산, 목초액 및 $\mathrm{EM}$ 활성액 처리 전·후 의 토양 미생물 중 방선균의 변화는 Fig. 4 에서 보는 바와 같 다. 처리 전 토양의 방선균수는 $21.08 \times 10^{3} \mathrm{CFU} / \mathrm{g}$ 이였으며, 처리 후에 방선균수를 조사한 결과 대조구에서 $23.12 \times 10^{3}$ $\mathrm{CFU} / \mathrm{g}$ 로 처리 전보다 다소 증가한 경향을 보였으며, 유기농 자재 처리에서도 다소 증가한 경향을 보였다. 유기농자재 처 리간에는 키토산 1,000 배액 처리구에서 $26.18 \times 10^{3} \mathrm{CFU} / \mathrm{g}$ 로 방선균수가 가장 많이 증가하였으나 처리간 뚜렷한 차이는 나타나지 않았다.

이상의 결과를 요약하면 세균, 사상균, 트리코데마 및 방선 균의 총 미생물수를 조사한 결과 균 종별 구성은 세균이 주종 을 이루었고, 사상균의 비율은 대체적으로 낮았다. 이는 자연

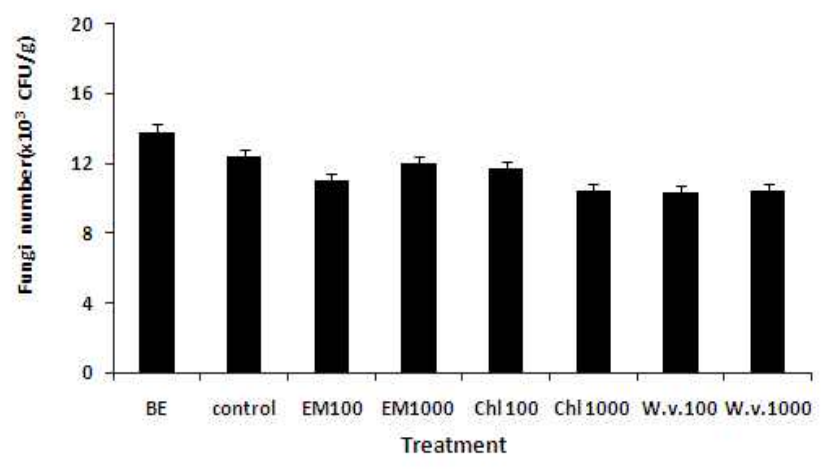

Fig. 2. Changes in the number of fungi in the soil for cultivation of Chinese cabbages.

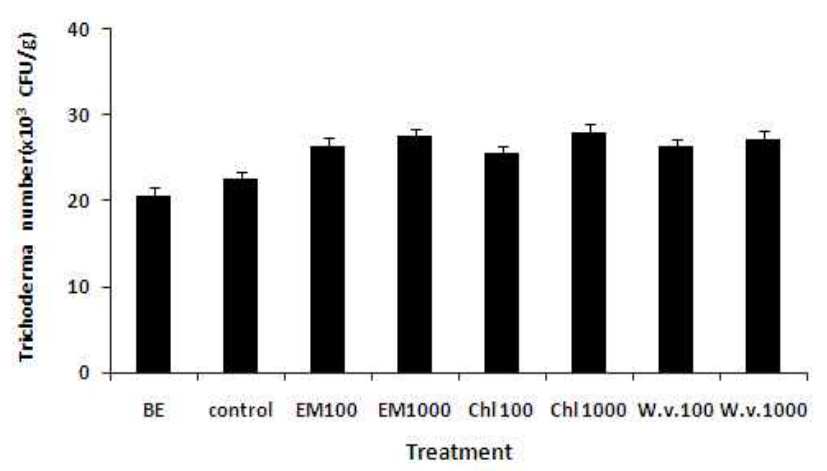

Fig. 3. Changes in the number of tricodema in the soil for cultivation of Chinese cabbages. 


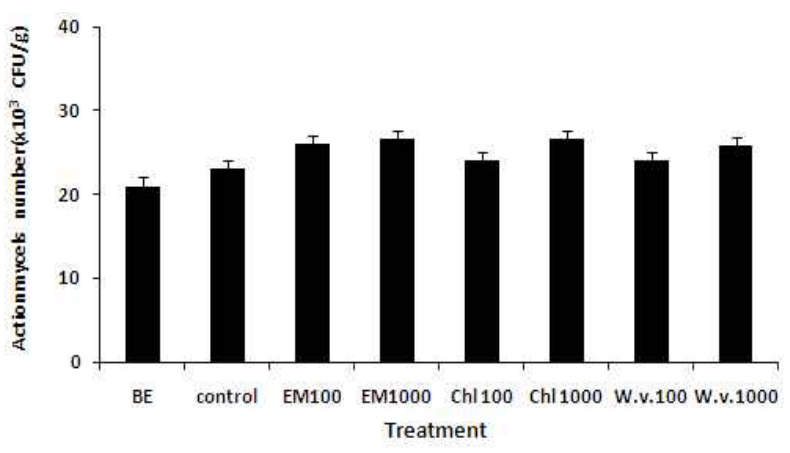

Fig. 4. Changes in the number of actinomycetes in the soil for cultivation of Chinese cabbages.

환경에 존재하는 미생물 상의 일반적인 구성과 미생물 개체수 의 변화를 보여 주는 것이다. 유기농자재를 3 회 엽면살포하고 배추를 수확한 다음 미생물상을 조사한 결과 유기농자재 처리 전에 비해 세균, 방선균 및 트리코데마수는 일정한 비율로 증 가하였고, 사상균수는 약간 감소하였으나 일정한 경향은 없었 다. 특히 키토산 1,000 배액 처리구에서 세균, 트리코데마 및 방선균이 증가하였고, 사상균이 감소하였는데 이와 같은 결과 는 키토산 처리로 토양 중의 방선균 활동이 증가되고 사상균 의 활동이 일시적으로 억제되었다는 Lee 등[14]의 보고와 유 사한 경향을 보였다.

\section{고 찰}

유기농자재인 키토산, 목초액 및 $\mathrm{EM}$ 활성액 처리에 따른 배추의 생육 및 토양 미생물상의 변화에 관한 연구결과를 종 합하면 유기농자재 처리에 따른 배추의 생육특성은 대조구에 비해 유기농자재를 엽면살포한 처리구에서 생육이 다소 높게 나타났으며, 유기농자재 간에는 키토산이, 처리농도 간에는 키토산 1,000 배액 처리구에서 엽장, 엽폭, 총 엽수, 주중, 구중, 구고 및 구폭 등이 증가하였는데, 이는 키토산에는 식물 체내 의 성장활성제인 Hexosamine의 증가와 키틴, 키토산의 분해 효소인 키티나제, B-13, 글루키나제 작용으로 생리활성이 높아 배추의 생육이 촉진된 것으로 판단된다[4]. Jeong 등[7]은 키토 산, 목초액 및 $\mathrm{EM}$ 의 농도를 각각 100 배, 500 배 및 1,000배액으 로 희석하여 토마토의 초기생육 특성을 조사한 결과 대조구에 비해 유기농자재를 사용한 처리구에서 생육이 양호하였고, 처 리간에는 키토산 500 배액 처리구에서 초장, 엽면적 및 과중 등이 양호하였다고 보고하였는데 본 시험에서는 500 배 엽면 살포 농도가 없어 1,000 배액 농도에서 생육이 양호하게 나타 났는데 이런 결과로 볼 때 100 배액보다는 500 배액 및 1,000 배 액 처리에서 생육이 좋아지는 것으로 판단되며, 추후 500 배액 및 1,000 배액 처리농도에서 작물별, 토성별로 연구가 계속 진 행되어야 할 것으로 사료된다. Lee 등[14]은 콩나물 재배시 키 토산 처리구가 대조구에 비해 $25.4 \%$ 의 높은 성장률을 보이고, 중량 또한 $8.5 \%$ 의 증가를 보인 보고와 Song 등[19]은 Chitosan
과 목초액 엽면살포에 의한 감자 플러그 삽목묘의 발근 및 괴경형성효율 시험에서 삽목 10 일후부터 4 일 간격으로 5 회 동안 Chitosan과 목초액을 무처리, $500 \mathrm{ppm}, 1,000 \mathrm{ppm}$ 및 $2,000 \mathrm{ppm}$ 처리 결과 Chitosan 500 1,000 ppm 및 목초액 $2,000 \mathrm{ppm}$ 의 농도에서 플러그묘의 초장, 엽수 뿐만 아니라 지상부, 지하부의 묘질이 양호해졌다고 보고와 비슷한 결과를 얻었다.

토양 미생물상 분설결과 무처리구인 대조구에 비해 유기농 자재를 처리한 시험구가 세균, 방선균 및 트리코데마수는 일 정한 비율로 증가하였으나 사상균수는 약간 감소한 경향을 보였다. 이러한 결과로 볼 때 토양 중의 생물, 특히 세균의 활성은 주변 토양의 입자나 식물뿌리와 밀접한 관계를 가지고 있으며, 전반적으로 유기농자재 처리가 무처리에 비해 배추의 생육이 좋아졌는데 이는 유기농자재가 배추의 생육촉진에 기 여하는 것도 있지만 대부분 토양중의 미생물상에 영향을 미침 으로서 토양 미생물수와 양이 증가함으로 근권이 활성화되어 지상부인 작물생육도 다소 양호해지는 것으로 판단된다. 특히 유기농자재를 엽면살포함으로서 세균수는 증대되고, 사상균 수는 감소하므로 B/F (Bacteria/Fungi) 비율이 증가하는 것으 로 나타나 B/F (Bacteria/Fungi) 비율이 작물생육에 영향을 초래한 것으로 판단된다. Uhm 등[23]은 키토산과 목초액 처리 가 고추의 생육 및 양분흡수에 미치는 영향에서 키토산 2,000 배액과 목초액 200배액을 경엽살포와 토양관주를 한 후 미생 물상을 조사한 결과 사상균수는 관행에 비해 밀도가 감소하는 경향을 보였다고 보고하였는데, 본 시험에서도 희석배수는 상 이하였으나 결과는 이와 유사한 경향을 보였다. 일반적으로 키토산는 토양 중 방선균의 밀도를 증가시킴으로서 병원성 사상균을 억제시키기 위한 수단으로 사용되어 왔는데[23], 본 시험의 결과도 이와 비슷한 맥락으로 해석될 수 있다. 따라서 유기농자재의 구성 균종이 배추재배 토양에 안정적으로 정착 하여 생존하는 것으로 판단되어 진다.

유기농자재인 키토산, 목초액 및 $\mathrm{EM}$ 활성액 시험에 있어 처리농도에 따른 작물별, 지역별, 재배조건별 및 토질의 영향 에 대한 연구와 체내성분 변화 및 생리 장해현상 에 대한 연구 도 앞으로도 계속 수행되어야 할 것으로 본다.

\section{References}

1. Ahmad, J. S. and R. baker. 1987. Rhizosphere competence of tricoderma harzianum. Phytopathol. 77, 182-189.

2. An, G. M. 1998. Components of wood using carbide. Mokpo University Symposium 11-57.

3. El Ghaouth, A., J. Arul, R. Ponnampalam, and M. Boulet. 1991. Chitosan coating effect on storability and quality of fresh stawberries. J. Food Sci. 56, 1618-1620.

4. Hadwiger, L. A., and J. M. Beckman. 1980. Chitosan as a component of Pea-Fusarium solani interactions. Plant Physiol. $66,205-211$. 
5. Hirano, S. and N. Nagao. 1989. Effects of chitosan, pectic acid, lysozyme, and chitinase on the growth of several phytopahogens. Agric. Sio. Chem 53, 3065-3066.

6. Higa. 1993. Agricultural utilization of microorganisms and environmental conservation. pp.77-92, Horticulture Technical Information Center, Korea.

7. Jeong, S. J., J. S. Oh., W. Y. Seok., J. H. Kim., D. H. Kim, and W. B. Chung. 2006. Effect of chitosan, wood vinegar and EM on microorganisms in soil and early growth of Tomato. Korean J. Organ. Agric. 14, 433-443.

8. Jeong, S. J., J. S. Oh., W. Y. Seok., J. H. Kim., M. Y.Cho, and J. B. Seo. 2007. The effect of chitosan and wood vinegar treatment on the growth of eggplant and leaf lettuce. Korean J. Organ Agric. 15, 437-452.

9. Jo, S. T. 1998. Carbonized wood and materials developed standardized. Carbonized Wood International Symposium on Agricultural and Environmental Uses. 151-166.

10. Kendra, D. F, and A. Hadwiger. 1984. Characterization of the smallest chitosan oligomer that is maximally antifungal to Fusarium solani and elicits pisatin formation in pisum sativum. Exp. Mycol. 8, 276.

11. Khambunruang, W., W. Saenwong, S. Siriphanicharoen, and P. Phromnat. 1995. Efferciency of EM in increasing rice yield. pp. 98-102, In Seminar on the project for Researches into EM and the Effects of its use on Agriculture and Environment, Bangkok, Thailand

12. Kim, K. H. 1995. Agricultural research, based on tests. Rural development administration.

13. Lee, Y. H. and B. C. Jang. 2000. Identification and use of activated substance derived from the commercialized environmental friendly agro-materials on plant growth. pp. 337-345, Agro-Environment Research 2000. Department of Agro-Environment. National Institute of Agricultural Science and Technology. RDA.

14. Lee, Y. S. and C. O. Lee. 1999. Change of free sugars, lipoxygenase activity and effects of chitosan treatment during cultivation of soybean sprout. Korean J. Food Sci. Technol. 31,
$115-121$

15. Nishimura, K., C. Ishihara, S. Ukei, S. Tokura, and I. Azuma. 1986. Stimulaton of cytokine production in mice using deacetylated chitin. Vaccine 4, 151.

16. Kim, J. M., C. W. Son, H. P. Seo, B. J. Moon, S. K. Do, and J. W. Lee. 2002. Effect of microbial product on microorganisms in soil and growth of cabbage. Korean J. Life Sci. $12,515-522$.

17. Rural Development Administration. 2004. Frendly environment - Organic farming agricultural use manuals. Rural Development Administration.

18. Sharifuddin, H. A. H., M. F. Shahbuddin, and A. R. Anuar. 1996. Nature farming research in Malaysia: Effect of organic amendments and EM on crop production. pp. 145-150, In Parr, J. F., S. B. Hornick, and M. E. Simpson (eds.)., Proceedings of the third international conference on kyusei nature farming. U.S. Department of Agriculture, Washington, D.C., USA.

19. Song, C. K. and B. K. Kang. 1999. Effects of foliar application of chitosan and wood extraction on rooting and tuber formation of plug seeding in potatoes. Korean J. Organ. Agric. 8, 89-100.

20. Sugano, M., K. Yoshida, H. hashimoto, K. Enomoto, and S. Hirano. 1992. Hypocholesterolemic activity of partially hydrolyzed chitosan in rats. pp. 472-478, In Brine, C. J., P. A. Sandford, and J. P. Zikakis, Advances in chitin and chitosan, Elsevier Applied Science, London and N.Y.

21. Thukair, A. A. 2002. Effect of soil pollution on euendolithic cyanobacteria of the Arabian gulf. Environ. Microbiol. 4, 125-129.

22. Trewavas, A. 2001. Urban myths of organic farming. Nature 410, 409-410.

23. Uhm, M. J., H. C. Park., Y. H. Moon., K. C. Kim, and S. G. Han. 2002. Effect of chitosan and wood vinegar on the growth and nutrient absorption of Red Pepper (Capsicum annum L.). Society Envir. Control 11, 67-73.

\title{
초록 : 유기농자재인 키토산, 목초액 및 $\mathrm{EM}$ 활성액의 처리에 따른 배추의 생육과 토양 미생물상에 미치 는 영향
}

\author{
정순재 ${ }^{1} \cdot$ 조미용 ${ }^{1} \cdot$ 석운영 $^{1} \cdot$ 이상록 $^{2} \cdot$ 이형주 ${ }^{3} \cdot{\text { 오주성 }{ }^{1} \star}^{2}$ \\ ('동아대학교 생명자원과학대학, ${ }^{2}$ 동아대학교 공과대학, ${ }^{3}$ 몬산토 코리아)
}

본 연구에서는 유기농자재인 키토산, 목초액 및 $\mathrm{EM}$ 활성액 등을 공시재료로, 배추 정식 전에 100 배액 토양관 주 처리하고, 배추 정식 후 15 일 간격으로 엽면살포 농도를 100 배액과 1,000 배액으로 3 회 엽면살포한 후 배추의 생육 및 토양 미생물상의 변화에 대해 분석하였다. 유기농자재 처리에 따른 배추의 생육특성은 대조구에 비해 유기농자재 처리구에서 생육이 양호하게 나타났으며, 유기농자재 간에는 키토산 처리구에서 양호하였고, 특히 키토산 1,000 배액 처리구에서 생육이 양호하였으며, 주중이 $5.60 \mathrm{~kg}$ 으로 가장 무거웠다. 유기농자재 처리에 따른 토양 미생물상 변화는 대조구에 비해 유기농자재 처리구에서 세균, 트리코데마 및 방선균수은 증가한 경향을 보 였고, 사상균수는 약간 감소한 경향을 보였으나 처리간 일정한 경향은 없었다. 유기농처리구 간에는 키토산 1,000 배액 처리구에서 세균, 트리코데마 및 방선균수가 가장 많이 증가하였다. 